\title{
ELECTRON BACKSCATTERED DIFFRACTION OF ALUMINIUM ALLOY 7075 SAMPLES AFTER HEAT TREATMENT
}

\author{
G. Vaneetveld $^{1 *}$, A. Rassili ${ }^{1}$, J-C Pierret ${ }^{1}$, J. Lecomte-Beckers ${ }^{2}$ and H. V. Atkinson ${ }^{3}$ \\ ${ }^{1}$ ThixoUnit ULg, PiMW B56, University of Liège - Sart Tilman, 4000 Liège, Belgium \\ ${ }^{2}$ MMS, B52, University of Liège - Sart Tilman, 4000 Liège, Belgium \\ ${ }^{3}$ Department of Engineering, University of Leicester, University Road, Leicester LE1 7RH, UK
}

\begin{abstract}
The RAP process (Recrystallisation And Partial melting) is a reheating route used to give shearthinning and thixotropic behaviour to a billet of semi-solid material. This process uses the recrystallisation phenomenon to obtain globular solid grains surrounded by a liquid matrix. Recrystallisation of rolled 7075 aluminium alloys in the T6 condition is difficult because dispersoid particles pin the grain boundaries. Here we examine with Electron Backscattered Diffraction the presence of intermetallic phases in the structure after reheating to various temperatures in the semi-solid range and quenching. The presence of these particles could explain some of the microstructural behaviour at semisolid temperatures. In addition, EBSD is used to examine whether recrystallisation has occurred.
\end{abstract}

KEYWORDS: RAP, Thixoforming, 7075 Aluminium Alloys, Recrystallisation, Intermetallic particle, Pinning Force, Semi-solid.

\section{INTRODUCTION}

7075 aluminium alloys are used for their great mechanical properties in various fields like aeronautics. The high strength is due to the precipitates in the Al-Zn$\mathrm{Mg}-\mathrm{Cu}$ system. In this work, we focus on intermetallic particles. Reactions during cooling are given by Backerud et al. [1]; these include the liquidus between $630-622^{\circ} \mathrm{C}$, the formation of $\mathrm{Al}_{3} \mathrm{Fe}$ between 618 and $601^{\circ} \mathrm{C}, \mathrm{Mg}_{2} \mathrm{Si}$ between 568 and $550^{\circ} \mathrm{C}$, and $\mathrm{Al}_{2} \mathrm{Cu}$ and $\mathrm{MgZn}_{2}$ at $470-466^{\circ} \mathrm{C}$. Another particle that is observed due to its grain boundary pinning effect is $\mathrm{Al}_{18} \mathrm{Cr}_{2} \mathrm{Mg}_{3}$ (E-phase) [2].

The strengthening precipitates such as $\mathrm{Al}_{2} \mathrm{Cu}$ and $\mathrm{MgZn}_{2}$ are soluble in the solid matrix but the dispersoids (e.g. Ephase) which pin the grain boundaries and hence inhibit recrystallisation in 7075, are only soluble in the liquid, making this alloy very resistant to recrystallisation [3]. An electron microscope has to be used to observe the dispersoid particles as they are 0.5 to $2 \mu \mathrm{m}$ in size [3]. 7075 in the as-supplied state is usually rolled and in the T6 heat treated condition. TEM examination has shown very few dislocations are present [4]. The material is thought to be unrecrystallised and consists of elongated grains with subgrains within them [2]. The lack of dislocations means that any 'recrystallisation' during reheating is not conventional recrystallisation in the sense of being driven by a reduction in dislocation density as the high angle boundary moves through the structure. The processes which occur will, however, be described here as 'recrystallisation' as the microstructural appearance is very similar. This is discussed in detail in [2]. On reheating into the semisolid state, the first liquid to form is driven by the reaction between $\mathrm{MgZn}_{2}$ and $\mathrm{Al}_{2} \mathrm{Cu}$, both hardening precipitates as opposed to dispersoids. This is consistent with the EDX analysis of samples quenched from the semisolid state, where the quenched liquid contains $\mathrm{Al}, \mathrm{Cu}, \mathrm{Zn}$ and $\mathrm{Mg}$. It does not contain $\mathrm{Cr}$, which would be present if $\mathrm{E}$ phase particles were forming liquid. These particles are therefore still pinning the boundaries and inhibiting recrystallisation. Once liquid starts to form, it penetrates pre-existing boundaries (including sub-boundaries). However, the E-phase particles are still pinning the elongated boundaries, although in places this pinning starts to break down. The mechanism for this is thought to be as follows [5]: a high angle boundary bows between two pinning E-phase particles under the driving force for grain growth at high temperature; the bowed boundary encounters a pool of liquid formed as a result of the reaction of the strengthening precipitates with the aluminium matrix; liquid wets the boundary and runs along to encounter an E-phase particle which then dissolves in the liquid, allowing the boundary to become unpinned and recrystallisation (i.e. the migration of the high angle boundary) to occur $[2,5]$.

Thixoforming involves forming alloys in the semisolid state to near net shaped products [6-8]. The required spheroidal microstructure can be obtained by a number of routes, including the Strain Induced Melt Activated method (SIMA) [9] and Recystallisation And Partial melting (RAP) [10]. The material is worked, e.g. by extrusion, and then reheated. Recrystallisation occurs (generally below the solidus but with 7075 above the

\footnotetext{
* Corresponding author: ThixoUnit ULg, PiMW B56, 4, Boulevard de Colonster, 4000 Liege, Belgium, Phone: +32 43615951, fax: +32 (0) 4361 5948, Fax: +32 (0) 4361 5959, E-mail: g.vaneetveld@ulg.ac.be
} 
solidus) and the liquid penetrates the recrystallised boundaries to give the spheroidal structure. The first liquid to form tends to form at grain boundaries because these are generally areas with high solute concentrations. The goal of this study is to understand the microstructure during reheating in more detail and hence to control the recrystallisation process, potentially shortening the heating cycle and increasing productivity for wrought alloy thixoforming. In addition, an issue in terms of understanding the microstructure is clarifying whether the as-supplied feedstock material is in the unrecrystallised condition despite having been rolled at temperatures above room temperature.

\section{EXPERIMENTAL}

Billets of feedstock (rolled bar@ @ T651) and feedstock heat treated with different heating cycles are analysed to show the influence of the final temperature on the microstructure. For this, five billets $(30 \mathrm{~mm}$ diameter by $59 \mathrm{~mm}$ height), cut from 7075 rolled bar supplied by Wilsons Plc ( $\mathrm{Al}-5.88 \mathrm{Zn}-2.45 \mathrm{Mg}-1.54 \mathrm{Cu}-0.20$ $\mathrm{Cr}-0.18 \mathrm{Fe}-0.10 \mathrm{Si}-0.06 \mathrm{Mn}-0.025 \mathrm{Ti}$ ), were heated by induction $(2 \mathrm{kHz})$ at the University of Liège. The five billets each had different final hold temperatures between the solidus and the liquidus $\left(497^{\circ} \mathrm{C}, 529^{\circ} \mathrm{C}, 553^{\circ} \mathrm{C}, 577^{\circ} \mathrm{C}, 597^{\circ} \mathrm{C}\right.$ ) (see Fig. 1) but the cycle length and the final step length $(60 \mathrm{~s}$ at final temperature to let kinetic transformations occur) [11] were the same. Temperatures were monitored with two K-type thermocouples which were attached in the positions TC1 and TC2 as shown in figure 2. The billets were quenched from the holding temperature into water.

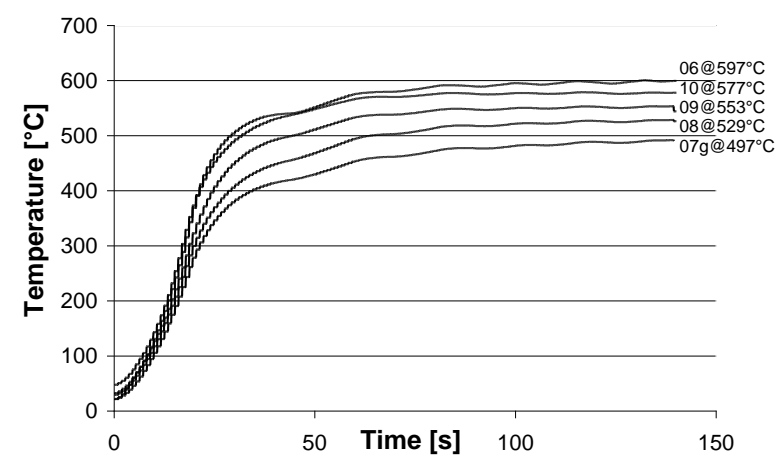

Fig. 1:Five heating cycles at different final temperatures.

The particles were observed with a Field Emission Gun Scanning Electron Microscope (FEGSEM) at the University of Leicester.

\section{Electron Backscattered Diffraction (EBSD)}

The feedstock and all heated samples were cut by a vertical hacksaw as described in figure 2 . The section analyzed by EBSD is the middle part. Samples were ground and polished. For EBSD, the sample is mounted on a plate and the plate is at $70^{\circ}$ to the electron beam. This caused difficulty in the analysis because there was a tendency for the sample to drift by about $200 \mu \mathrm{m}$ in an analysis period of 10 hours because of gravity. The particles being sought are about $0.5-2 \mu \mathrm{m}$ size and, therefore, the best compromise between speed and precision in

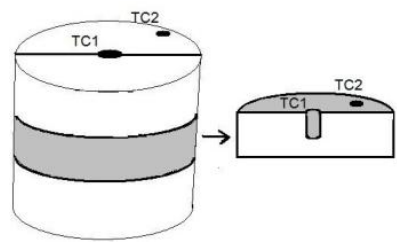

Fig. 2: Samples cut by hacksaw and polished. TC1 and TC2 are thermocouple positions.

detection was found to be to select eight Kikuchi bands and a step of $0.3 \mu \mathrm{m}$ on a $875 \mu \mathrm{m}^{2}$ surface for the EBSD analysis.

Intermetallic phase crystallographic data was taken from the Pearson's Handbook [12].

\section{RESULTS AND DISCUSSION}

\subsection{Analysis of intermetallic particles}

The FEGSEM was used to observe intermetallic particles in each of the 5 billets with different final temperatures and in the starting material. Only the four main steps of microstructure variation are shown in figure 3. In figure 3 , the phases predicted by Backerud have been targeted in the analysis and are all shown on one micrograph (hence 'All phases'). On EBSD micrographs, each colour (shown here in terms of greyscale) indicates a different grain orientation.

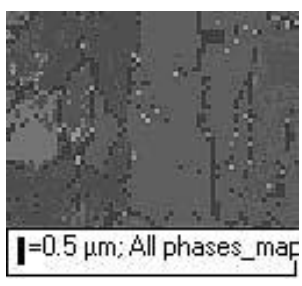

a) All phases@20ㄷ

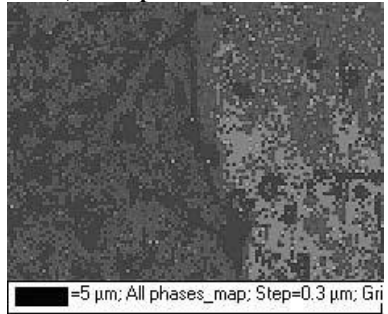

c) All phases@ $@ 553^{\circ} \mathrm{C}$

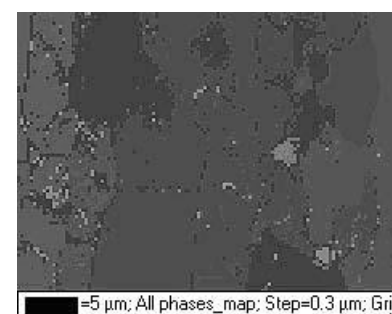

b) All phases @ $529^{\circ} \mathrm{C}$

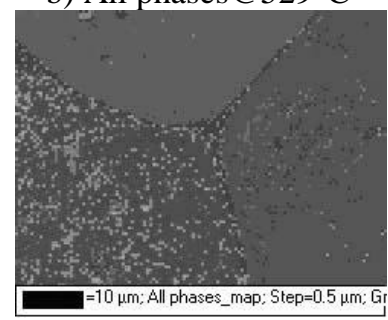

d) All phases@ $597^{\circ} \mathrm{C}$
Fig. 3: EBSD results showing all selected phases $\left(\mathrm{Al}_{2} \mathrm{Cu}, \mathrm{MgZn}_{2}, \mathrm{Mg}_{2} \mathrm{Si}, \mathrm{Al}_{3} \mathrm{Fe}, \mathrm{Al}_{18} \mathrm{Cr}_{2} \mathrm{Mg}_{3}\right)$ for main temperatures steps.

The following observations were made in the centre of the billet near the point of thermocouple contact. (It should be noted that ' $\left(\mathrm{liq} @ \mathrm{x}^{\circ} \mathrm{C}\right)$ ' indicates the temperature at which the particles are expected to start to dissolve based on the Backerud et al. [1] experiments). 
$-\mathrm{Al}_{\mathbf{2}} \mathbf{C u}$ (liq@470 ${ }^{\circ} \mathrm{C}$ ): The EBSD does not detect any $\mathrm{Al}_{2} \mathrm{Cu}$ particles in the feedstock or in the samples heat treated at higher temperatures.

$-\mathbf{M g Z n}_{2}$ (liq@470 $\mathrm{C}$ ): A few particles are observed in the material (highlighted in white in Fig. 4 which shows the same fields of view as Fig. 3). At higher temperature, particles are close to the solidified liquid as seen on figure $4 \mathrm{~d}$ ).

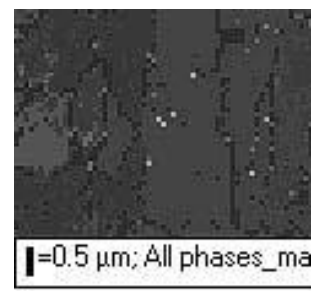

a) $\mathrm{MgZn} n_{2} @ 20^{\circ} \mathrm{C}$

c) $\mathrm{MgZn}_{2} @ 553^{\circ} \mathrm{C}$

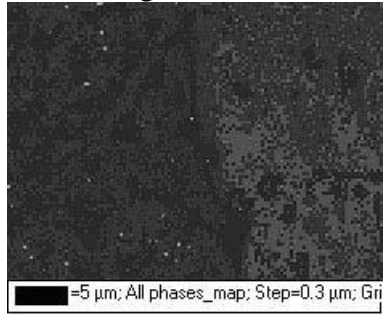

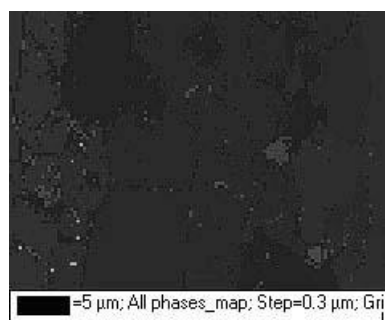

b) $\mathrm{MgZn}_{2} @ 529^{\circ} \mathrm{C}$

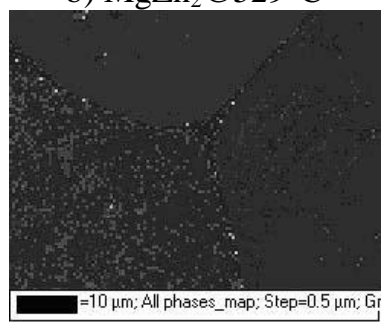

d) $\mathrm{MgZn}_{2} @ 597^{\circ} \mathrm{C}$
Fig. 4: EBSD results showing $\mathrm{MgZn}_{2}$ in white for main temperatures steps.

- $\mathbf{M g} g_{2} \mathrm{Si}$ (liq@570 $\mathrm{C}$ ): These particles are numerous and are distributed fairly evenly inside grains (Fig. 5 - again same fields of view as for Fig. 3 with, this time, the $\mathrm{Mg}_{2} \mathrm{Si}$ highlighted in white. The same principle is used with each of the subsequent sets of micrographs i.e. highlighting the phase in question in white).

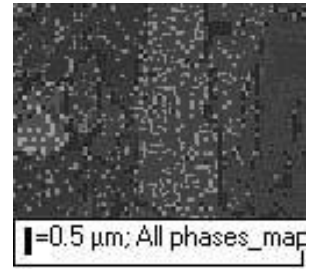

a) $\mathrm{Mg}_{2} \mathrm{Si} @ 20^{\circ} \mathrm{C}$

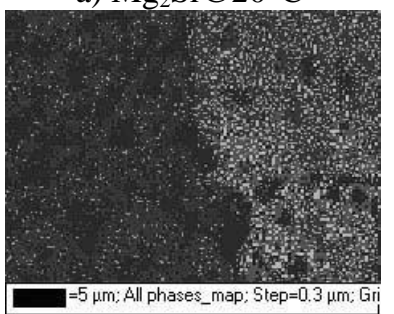

c) $\mathrm{Mg}_{2} \mathrm{Si} @ 553^{\circ} \mathrm{C}$

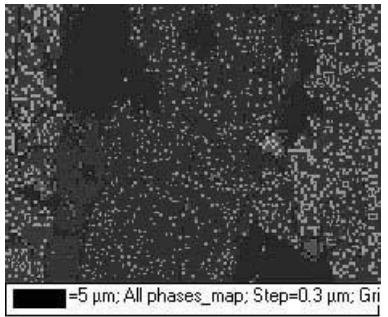

b) $\mathrm{Mg}_{2} \mathrm{Si} @ 529^{\circ} \mathrm{C}$

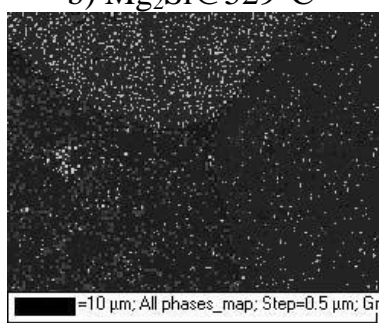

d) $\mathrm{Mg}_{2} \mathrm{Si} @ 597^{\circ} \mathrm{C}$
Fig. 5: EBSD results showing $\mathrm{Mg}_{2} \mathrm{Si}$ in white for main temperatures steps.

$-\mathbf{A l}_{3} \mathbf{F e}$ (liq@620 $\left.\mathrm{C}\right)$ : The concentration of these particles is higher in some grains than others.

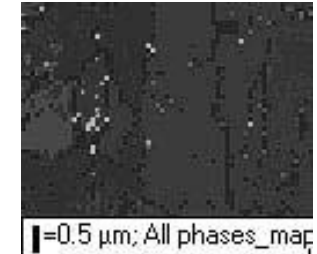

a) $\mathrm{Al}_{3} \mathrm{Fe} @ 20^{\circ} \mathrm{C}$

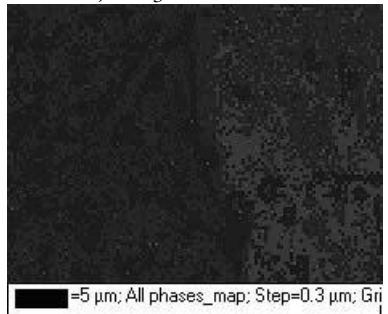

c) $\mathrm{Al}_{3} \mathrm{Fe} @ 553^{\circ} \mathrm{C}$

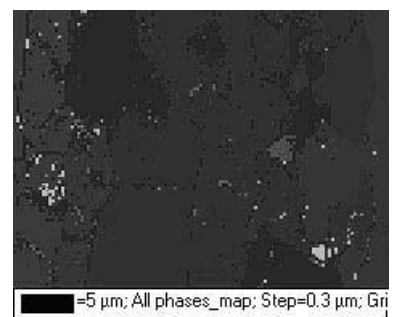

b) $\mathrm{Al}_{3} \mathrm{Fe} @ 529^{\circ} \mathrm{C}$

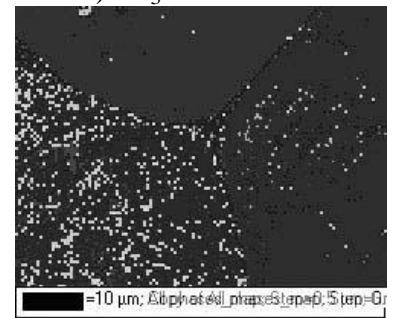

d) $\mathrm{Al}_{3} \mathrm{Fe} @ 597^{\circ} \mathrm{C}$
Fig. 6: EBSD results showing $\mathrm{Al}_{3} \mathrm{Fe}$ in white for main temperatures steps.

$-\mathbf{A l}_{18} \mathbf{C r}_{2} \mathbf{M g}_{3}$ (liq@ $970^{\circ} \mathrm{C}$ ): $\mathrm{Al}_{18} \mathrm{Cr}_{2} \mathrm{Mg}_{3}$ particles are numerous and have the same distribution as $\mathrm{Mg}_{2} \mathrm{Si}$. We note that at $597^{\circ} \mathrm{C}$, some particles remain in the grain boundary (grey circled in the figure $7 \mathrm{~d}$ )).

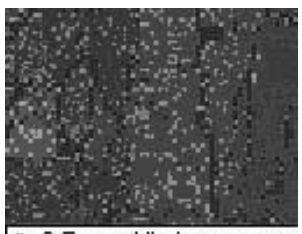

$\mathbf{I}=0.5 \mu \mathrm{m} ;$; All phases_mar

a) $\mathrm{Al}_{18} \mathrm{Cr}_{2} \mathrm{Mg}_{3} @ 20^{\circ} \mathrm{C}$

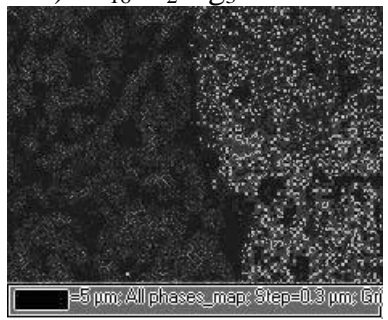

c) $\mathrm{Al}_{18} \mathrm{Cr}_{2} \mathrm{Mg}_{3} @ 553^{\circ} \mathrm{C}$

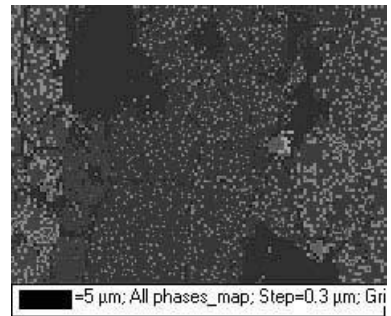

b) $\mathrm{Al}_{18} \mathrm{Cr}_{2} \mathrm{Mg}_{3} @ 529^{\circ} \mathrm{C}$

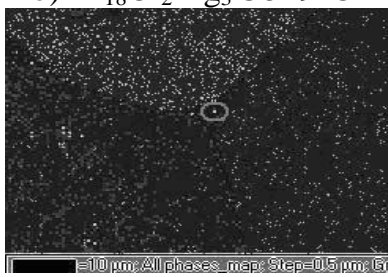

d) $\mathrm{Al}_{18} \mathrm{Cr}_{2} \mathrm{Mg}_{3} @ 597^{\circ} \mathrm{C}$
Fig. 7: EBSD results showing $\mathrm{Al}_{18} \mathrm{Cr}_{2} \mathrm{Mg}_{3}$ in white for main temperatures steps.

Results show that some intermetallic particles $\left(\mathrm{MgZn}_{2}\right.$, $\mathrm{Mg}_{2} \mathrm{Si}$ ) exist above the temperature indicated by Backerud et al. [1] as the dissolution temperature. This may be a kinetic effect as time is taken to reach equilibrium during heating. Alternatively, having dissolved in liquid during heating they could be reprecipitating during the quench as the quench is relatively slow $\left(34^{\circ} \mathrm{C} / \mathrm{s}\right)$ given the size of the sample.

$\mathrm{Mg}_{2} \mathrm{Si}$ and $\mathrm{Al}_{18} \mathrm{Cr}_{2} \mathrm{Mg}_{3}$ are more numerous than $\mathrm{MgZn}_{2}$ and $\mathrm{Al}_{3} \mathrm{Fe}$. $\mathrm{MgZn}_{2}$ and $\mathrm{Al}_{3} \mathrm{Fe}$ are not uniformly distributed in grains. 


\subsection{Analysis of grain orientation to detect subgrains}

In some deformed or recovered materials, a structure of subgrains may be formed within the grains. Subgrains are typically $\sim 1 \mu \mathrm{m}$ in size and are misoriented by only a few degrees. In contrast, recrystallised grains have a large misorientation from the parent grains. On EBSD micrographs of as-received material (e.g. figure 3 a)), each colour (shown here in terms of greyscale) indicates a different grain orientation. We note bands of colour which are elongated grains with sub-boundaries within them. There is no change in colour across the subboundary suggesting that recrystallisation has not occurred in the as-received material.

\section{DISCUSSION AND CONCLUDING REMARKS}

EBSD has been used to detect intermetallic phases expected to be present in aluminium alloy 7075 . This is the first time, to the best of the authors' knowledge this technique has been applied to study microstructural changes during reheating in 7075. The analysis compares as-received material (in the rolled and T651 heat treated state) with samples heated to different temperatures between the solidus and liquidus. The heating cycle is relatively short (less than 150s) and is followed by a quench. The size of the sample is such that the quench is quite slow. The short heating cycle is intended to mimic the cycle time which might be used in heating material for thixoforming. The essential aim in induction heating material for thixoforming is to obtain spheroidal solid grains surrounded by liquid. Data is available from Backerud et al. [1] for the expected reaction temperatures but the evidence is from cooling rather than from heating as in the experiments here.

The EBSD of the as-received material (compare Figs. 4 a), 5 a), 6 a) and 7 a)) shows a few $\mathrm{MgZn}_{2}$ and $\mathrm{Al}_{3} \mathrm{Fe}$ particles. $\mathrm{Mg}_{2} \mathrm{Si}$ and $\mathrm{Al}_{18} \mathrm{Cr}_{2} \mathrm{Mg}_{3}$ are distributed fairly uniformly through grains (although with some grains relatively free of particles; it is not clear why). After heating to $529^{\circ} \mathrm{C}$, the $\mathrm{MgZn}_{2}$ should have reacted to form liquid. However, there is some evidence it is still present suggesting that the heating cycle is too fast for equilibrium to be achieved (Fig. 4 b)). As expected, the other intermetallics are still present at $529^{\circ} \mathrm{C}$. At $553^{\circ} \mathrm{C}$ (see Figs. 4 c), 5 c), 6 c) and 7 c)), some $\mathrm{MgZn}_{2}$ still appears to be present. $\mathrm{Mg}_{2} \mathrm{Si}$ and $\mathrm{Al}_{18} \mathrm{Cr}_{2} \mathrm{Mg}_{3}$ are numerous in some grains but not in others. There is no evidence of $\mathrm{Al}_{3} \mathrm{Fe}$ even though this phase should not disappear until $620^{\circ} \mathrm{C}$. It is at around $553^{\circ} \mathrm{C}$ that the transition between elongated grains and round grains is occurring. Liquid appears around this temperature. Fig. 5 c) suggests that a boundary is becoming unpinned with the classic catenated appearance of the boundary running vertically through the image. The 'pools' of dark are probably solidified liquid as no phases are found here. At $597^{\circ} \mathrm{C}, \mathrm{MgZn}_{2}$ is present but in what was liquid at boundaries at temperature. It is therefore possible that this has formed from the liquid during the (relatively slow) quench. The other particles are now more evident but appear to be in some grains but not others. It is, again, not clear why. Spheroidal grains grow from $30 \mu \mathrm{m}$ diameter at $573^{\circ} \mathrm{C}$ to reach $100 \mu \mathrm{m}$ diameter at $597^{\circ} \mathrm{C}$.

We conclude: 1) That the heating cycle used in these experiments is probably too short for equilibrium to be achieved; but 2) the finding of a spheroidal microstructure suggests this length cycle may be appropriate for thixoforming. The temperature required will depend on the fraction liquid necessary for forming.

\section{ACKNOWLEDGEMENTS}

The authors gratefully acknowledge University of Liège and Walloon Region (First Europe Project) for their support. We would like to thank G. Clarke for the training on the EBSD and S. Salieri for the help in the sample preparation. The authors are grateful to COST 541 for funding to support a Short Term Scientific Mission to Leicester University for GV.

\section{REFERENCES}

[1] L. Bäckerud, E. Król, J. Tamminen, Solidification characteristics of aluminium alloys, vol. 1: Wrought Alloys, Skan Aluminium, Oslo (1986).

[2] H.V. Atkinson, K. Burke, G. Vaneetveld, Recrystallisation in the Semi-Solid State in 7075 Aluminium Alloy, Mater. Sci. Engng. A. 490 (2008) 266-276.

[3] Ayer Raghavan, J.Y. Koo, J.W. Steeds and B. K. Park, Metall. Trans. A 16A (1985) 1925-36.

[4] S. Chayong, Thixoforming processing of aluminium 7075 alloy, $\mathrm{PhD}$ Thesis, University of Sheffield, 2002.

[5] H.V. Atkinson, K. Burke, G. Vaneetveld, Recrystallisation in the Semi-Solid State in 7075 Aluminium Alloy, Esaform Conference 2008, DOI 10.0007/s12289-008-0220-z

[6] Z. Fan, Internat. Mater. Rev., 47 (2002) 49-85.

[7] H. V. Atkinson, Progress in Materials Science 50(3) (2005) 341-412.

[8] G. Vaneetveld, A. Rassili, J-C. Pierret, J. LecomteBeckers; Improvement of thixoforging of 7075 aluminium alloy at high solid fraction; Trans. Tech Publications, Solid State Phenomena Vols. 141-143, p. 707-712, Switzerland, 2008.

[9] K.P. Young, C.P. Kyonka, J.A. Courtois, Fine grained Metal composition. US Patent No. 4,415,374; 30 March 1982.

[10] D.H. Kirkwood, C.M. Sellars, L.G. Elias-Boyed, Thixotropic materials. European Patent No. 0305375 B1; 28 October 1992.

[11] G. Vaneetveld, A. Rassili, H. V. Atkinson; Influence of parameters during induction heating cycle of 7075 aluminium alloy with RAP process; Trans. Tech Publications, Solid State Phenomena Vols. 141-143, p. 719-724, Switzerland, 2008.

[12] P. Villars, Crystallographic Data for intermetallic phases, Pearson's Handbook Desk Edition, Vol. 1, ASM Int., 1997. 